\title{
The blurred boundaries between science and activism
}

\section{Andrea Bandelli}

\section{Abstract}

Science and activism are terms which are usually seen as quite separate. Yet, they are inextricably linked, even more so as techno scientific progress permeates contemporary society. The five commentaries in this series provide insights for a discussion about how the (apparent) separation between "value laden" activism and "value free" science is in fact very thin, and how science communication can play a key role in ensuring reflexivity and self criticism in science.

When used together, the terms "science" and "activism" usually provoke an uncomfortable reaction. For some, socially and often politically laden activism, striving to bring about social change, seems to be in stark contrast to the neutrality of scientific research, which is concerned with producing knowledge. Activism adds a layer of social purpose to the endeavour of research, and might compromise its objectivity. An activist purpose might therefore distort or even "corrupt" the enterprise of science. Sometimes political or religious activism even stands against scientific research, and it tries to stop or prohibit certain developments. At the same time, the work of activists strengthens the social relevance of science: major advancements in medicine and environment for instance were made possible by the work of activist movements in collaboration with scientists, as documented in the seminal work by Epstein [1995]. Many activists rely on scientific knowledge to substantiate their claims, but at the same time they criticize the scientific institutions as being disconnected from society, or even as serving industrial or partisan interests.

Science communication is not immune from this intricate relationship with activism either. The debates around climate change have highlighted how "neutrality" is an elusive concept when the very nature of what is being communicated is politically, economically and socially laden. As Bernhard Isopp asks in his commentary in this issue, "what could it possibly mean to "de-politicize" an inescapably political issue?' Being able to question the neutrality of science (communication), and the legitimacy of its practices is essential in order to have a healthy, self-critical and reflexive professional field. This does not mean taking an activist position (although as these commentaries show, sometimes activism is the only option). Rather, it requires reflecting on the values that drive the scientific endeavour and how they interface, overlap, reinforce or conflict with social and political ones. 
To stimulate the dialogue on these issues, we have invited five authors to map out the various dimensions of science and activism. These commentaries provide us with insightful, telling and personal accounts of why the association between science and activism can be a troubled one, and they expose the normative, epistemological, and ethical layers that define activism in science.

Gwen Ottinger dismisses the criticism of activist science as "value laden" science, because, she argues, all science is in fact value laden. Scientists constantly make value judgments, and different judgments lead to different interpretations of reality. Exposing the diversity of these judgments facilitates a much-needed broad discussion on the priorities of science and research. And to achieve this level of transparency, citizen science and science communication play a key role. Bernhard Isopp starts with the juxtaposition of science, an enterprise which is supposed to be value-free, and activism, an enterprise which is value laden. His analysis of the boundaries between science and activism reveals that science, and importantly for the readers of this journal, science communication, can in fact comply with rigorous epistemic standards and at the same time be activist in pursuing social and political action.

Marta Conde provides several examples of the dynamic inter-relationships between researchers and activists, and describes how activists can both develop new knowledge and exploit existing knowledge. When activism is a driving force for research, new forms of collaboration between citizens and scientists emerge, leading to co-production of knowledge and empowerment. In this process universities get new roles as well, connecting research with societal interests. The interchange between researchers, grassroots organizations and citizens entails conflicts and risks as well; however, Conde argues, the benefits are too valuable to dismiss the collaboration between scientists and activists as troublesome.

Activism was the obligatory path for two contributors, Jacques Testart and Alain Trautmann, who argue that there is a lack of reflexivity in the professional enterprise of science and research, and suggest that activism is sometimes a necessary choice in order to be a scientist today. Trautmann gives a poignant portrait of how the current policies governing research are actually compromising the work of scientists. Three paradoxes are stifling the activity of researchers: the fact that publications are used now as evaluation tools rather than communication instruments; the inflation of short term, temporary research positions leading to a "bubble" ready to explode; and the new public management style, which is incompatible with the needs of scientific organizations. These factors led to several uprisings in recent years, mobilizing young researchers all over Europe which had no choice but to become activists in order to safeguard the integrity of science, endangered by the policies supposed to govern it. Jacques Testart offers his personal account of how he found himself to be an activist because he started questioning the legitimacy and presumed neutrality of scientific research. This kind of criticism is still considered "not done" among the profession of science, Testart argues, and those who want to engage in this criticism are automatically considered militant activists. And yet, he argues, scientists cannot escape the consequences of scientific research: "Being a researcher should not prevent you from being a citizen, and therefore, being responsible for the consequences of your acts" he warns. 
The common thread that emerges from these commentaries is that there are fewer barriers between activism and science than we might think; and that the borders between socially motivated, value driven activism and the pursuit of scientific knowledge are in fact osmotic membranes. Activist science is the result of this osmotic process. The challenge for science communication, these commentaries point out, is to keep studying this process to identify where relevant issues in science and society lie; where tensions accumulate; where benefits are greatest; where the dangers can hit hardest.

References

Epstein, S. (1995). 'The Construction of Lay Expertise: AIDS Activism and the Forging of Credibility in the Reform of Clinical Trials'. Science, Technology $\mathcal{E}$ Human Values 20 (4), pp. 408-437. DOI: 10.1177/016224399502000402.

Author

Andrea Bandelli is a scholar in science communication and an advisor for science education projects and institutions. He has developed, managed, evaluated and directed several international projects on science, art, democracy and public participation in collaboration with Ecsite, the European network of science centers and museums. E-mail: andrea@bandelli.com

Bandelli, A. (2015). 'The blurred boundaries between science and activism'. JCOM 14 (02), C01. 